\title{
UAV Application for Landslide Mapping in Kuningan Regency, West Java
}

\author{
Humam Abdurrasyid Afif ${ }^{1}$, Rokhmatuloh ${ }^{1, *}$, Ratna Saraswati ${ }^{1}$, and Revi Hernina ${ }^{1}$ \\ ${ }^{1}$ Department of Geography, Faculty of Mathematics and Natural Science, University of Indonesia, Jakarta - Indonesia
}

\begin{abstract}
Kuningan Regency is one of the districts in West Java Province with a high rate of landslide events, especially in the southern part where its hilly landscape is dominated with a steep slope. Due to its vulnerability because of cracked soil after the landslide events, landslide locations in Kuningan Regency might only be safe if surveyed using the unmanned aerial vehicle (UAV). Therefore, in this study, DJI Phantom 4 Pro was flown to capture images of landslide locations with a $10 \mathrm{~cm}$ spatial resolution. Image processing was conducted to generate Orthophoto and Digital Surface Model (DSM) to give information about the direction and area of landslides. Two sub-districts where landslides occurred, namely Darma and Selajambe, were chosen for landslide mapping using UAV. Results show that in Darma Sub-district, the landslide area is approximately 7,026 m2, while in Selajambe Subdistrict is around $8,699 \mathrm{~m} 2$. The study results are very useful to analyze the factors affecting landslide events such as slope.
\end{abstract}

Keywords: Landslide; UAV; Orthophoto; DSM.

\section{Introduction}

Landslide is a type of natural disaster that usually occurs in mountainous areas [1]. Landslide is defined as movements of soil mass, rocks or materials sliding down the slope [2]. Landslide is a downslope movement of rock or soil, or both, occurring on the surface of ruptureeither curved (rotational slide) or planar (translational slide) rupture-in which much of the material often moves as a coherent or semi coherent mass [3].

Landslides can be caused by natural processes, namely the changes in the structure of the face of the earth as a physical phenomenon in forming slope stability [4]. Landslide occurs because of the unbalance of 2 forces gripping on the slopes, namely the retaining force and the sliding force [5]. The slope's retaining force is influenced by the water content, the weight of the soil mass, the soil's physical properties and the slope itself [6].

One of the technique to get data with fast and accurate through aerial photography is using Unmanned Aerial Vehicle (UAV). UAV technology can be used easily and time efficiently. The obtained data have a high spatial resolution so that errors in object identification or measurement can be minimized. UAV application can make it easier for users to identify objects that are difficult to reach [7].

Kuningan Regency is one of several districts in West Java with a high rate of landslide events, especially when entering the early rainy season. The Kuningan District Disaster Management Agency (BPBD) recorded at least 82 villages in 15 sub-districts in Kuningan
Regency during the rainy season had landslides. The landslide events occurred mostly in areas with steep slope conditions. The occurrence of landslide in Kuningan Regency is difficult to predict and therefore it might be a danger for survey personnel to map the landslides locations with conventional tools. Consequently, a survey method without touching the landslide locations such as UAV is highly needed. Hence, this paper aims to map the locations of the landslides in Kuningan Regency using UAV.

\section{Methodology}

\subsection{Study Area}

Kuningan Regency is located between $06^{\circ} 47^{\prime}-07^{\circ} 12^{\prime}$ South Latitude and $108^{\circ} 23^{\prime}-108^{\circ} 47^{\prime}$ East Longitude. Kuningan Regency is situated in the eastern part of West Java Province with an area of around 119,571.12 hectares. The topography in Kuningan Regency is quite varied, from the lowlands to the mountains with its highest peak on Mount Ciremai $(3,078 \mathrm{~m})$. Most of Kuningan Regency are placed between 100 to 1000 meters above sea level. In this altitude, slope can be found in most of the landscapes [8].

\footnotetext{
*Corresponding author: rokhmatuloh.ssi@ui.ac.id
} 


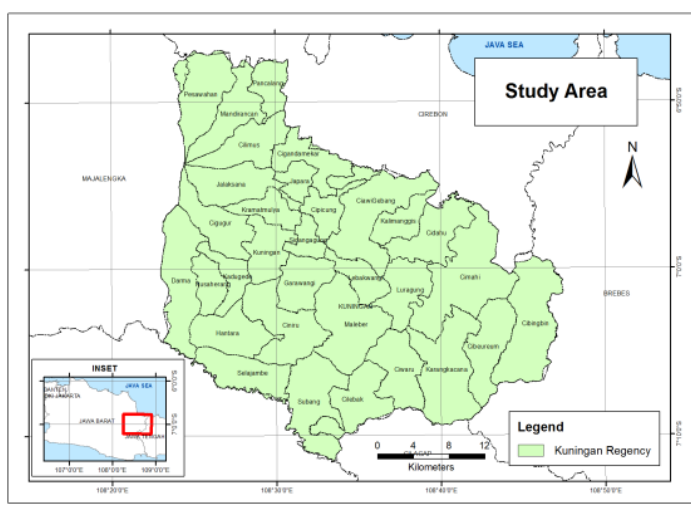

Fig. 1. Study Area

\subsection{Unmanned Aerial Vehicle (UAV)}

In general, UAVs can be divided into 2 types, fixed wing, and rotor. Both types of UAVs have their advantages and disadvantages. Fixed wing types have more coverage area, but require a fairly wide and flat area for take-off and landing [7]. Unlike the rotor type UAV which has the ability to hover (stop in the air) and can be flown in all fields because it does not require a large location for take-off or landing, but the range of this type is narrower than fixed wing type $[9,10]$.

The UAV used in this study is the multirotor type (quadcopter), namely the DJI Phantom 4 Pro. One of the devices in this UAV is the front sensor, which detects the obstacle in front of it. Before taking aerial photographs, flight plan is made according to the area to be covered. The duration of aerial photography takes between 5-15 minutes depending on the area to be taken. UAV is flown at an altitude of 100 meters from the flight location to get detailed and clear images [11]. Picture of a DJI Phantom 4 Pro is shown in Fig. 2.

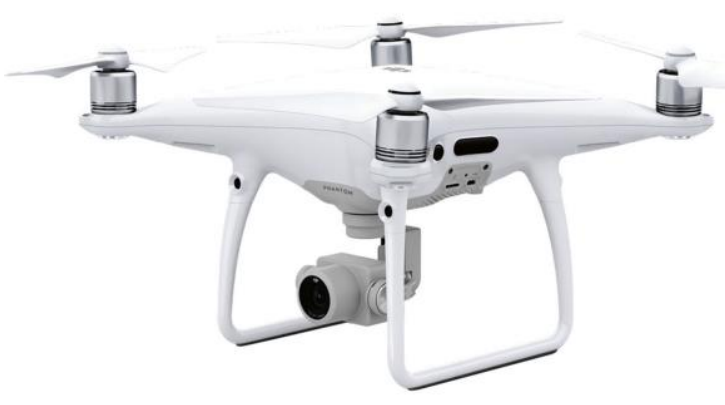

Fig 2. DJI Phantom 4 Pro (Quadcopter)

Rotor type and camera specifications from DJI Phantom 4 Pro can be observed in Table 1 and Table 2 [11].

Table 1. UAV Specification

\begin{tabular}{|l|l|}
\hline \multicolumn{2}{|c|}{ UAV Specification } \\
\hline Type & Quadcopter \\
\hline Weight & $\begin{array}{l}1388 \text { gram (Battery \& } \\
\text { Propellers Included) }\end{array}$ \\
\hline
\end{tabular}

\begin{tabular}{|l|l|} 
Flight Time & Approx. 30 minute \\
\hline Battery & $5870 \mathrm{mAh}(89.2 \mathrm{Wh} / 15.2 \mathrm{~V})$ \\
\hline $\begin{array}{l}\text { Remote Control } \\
\text { Transmission Distance }\end{array}$ & $3.5 \mathrm{~km}$ \\
\hline Speed & $31 \mathrm{mph}-45 \mathrm{mph}$ \\
\hline Wind Speed Resistance & $10 \mathrm{~m} / \mathrm{s}$ \\
\hline
\end{tabular}

Table 2. Camera Specification

\begin{tabular}{|c|c|}
\hline \multicolumn{2}{|r|}{ Camera Specification } \\
\hline Sensor & $1 " \mathrm{CMOS}$ \\
\hline Lens & FOV $84^{\circ} 8.8 \mathrm{~mm} / 24 \mathrm{~mm}$ \\
\hline Resolution & $20 \mathrm{M}$ \\
\hline Image Size & $\begin{array}{l}\text { 3:2 Aspect Ratio: } 5472 \times 3648 \\
\text { 4:3 Aspect Ratio: } 4864 \times 3648 \\
\text { 16:9 Aspect Ratio: } 5472 \times 3078\end{array}$ \\
\hline Photo Format & JPEG, DNG (RAW), JPEG + DNG \\
\hline ISO & $\begin{array}{l}\text { Video: } \\
100 \text { - } 3200 \text { (Auto) } \\
100 \text { - } 6400 \text { (Manual) } \\
\text { Photo: } \\
100 \text { - } 3200 \text { (Auto) } \\
100-12800 \text { (Manual) }\end{array}$ \\
\hline
\end{tabular}

(Source : [11])

\subsection{Data used}

Data obtained from UAV are JPEG format photos that already have geographic references or coordinates. The number of photos obtained is approximately 200 photos from several flights. Only the best photos that will be processed further using Agisoft Photoscan software [12].

The first step of the process is to Align Photo. In this stage, the photos will be aligned according to the coordinates. The second step is to make Dense Point Cloud. Dense Point Cloud is based on a combination of estimated camera position and depth information from each photo. After the Dense Point Cloud process was successfully created, the next is to make a mesh. PhotoScan reconstructs a 3D polygonal mesh representing the object surface based on the dense or sparse point cloud according to the user's choice. The results from the mesh data were then processed into Digital Surface Model (DSM) and Orthophoto [12].

\section{Result}

The final results obtained from UAV are Orthophoto and Digital Elevation Model (DEM). From Orthophoto, georectified photos are obtained, while DEM provides height in the form of 3-D images. Herein, DEM comes 
from DSM which displays any object on the ground such as trees and buildings.

From Orthophoto images, we can identify the locations and the area affected by the landslides. Orthophoto images can also show which areas are still vulnerable or having crack soil after landslide events. Based on Orthophoto around the landslide area, it can be identified which areas should be immediately accessed or rehabilitated. This identification will be very useful in mitigation efforts for people who live or work in land affected by landslides. In addition, it can also be a warning to the public not to approach these areas which are still vulnerable after landslides.

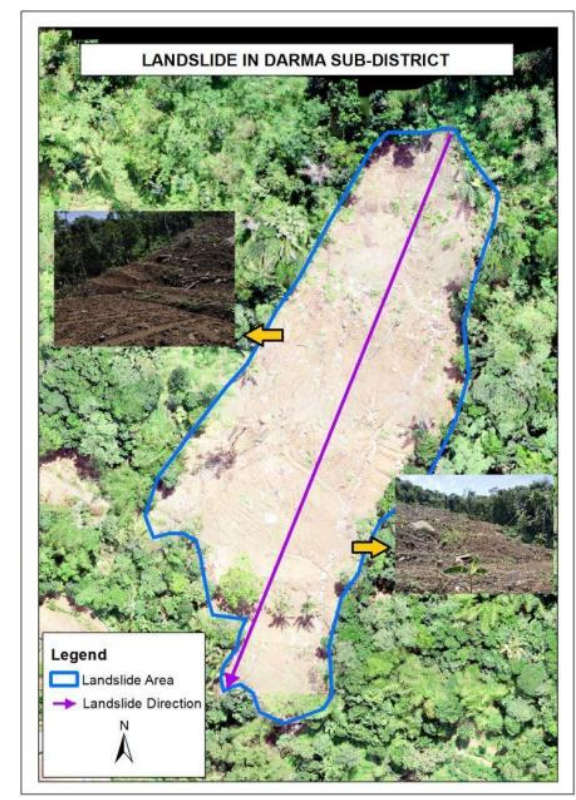

Fig 3. Landslide in Darma Sub-District

The first aerial photography was taken in Darma Sub-district. This landslide disaster occurred in plantation areas close to residential areas. At this location, landslide is caused by the high intensity of rainfall. Furthermore, the hill towards human settlements has a slope of more than $45 \%$. This landslide has an area of about $7,025.6 \mathrm{~m}^{2}$, while the direction of the landslide is facing southwest. The landslide location in Darma Sub-district can be seen in Fig. 3.

The DSM of the landslide location in Darma Subdistrict can be observed in Fig. 4. It can be estimated from Figure 4 the height of the avalanches that occurred above the hill in the north direction indicated by dark brown color. The landslide starts from the peak of the slope with an altitude of \pm 500 meters above sea level (ASL) to the sediment area with an altitude of \pm 450 meter ASL. The length of this avalanche approximately 150-160 meters from its peak area to its sediment area.

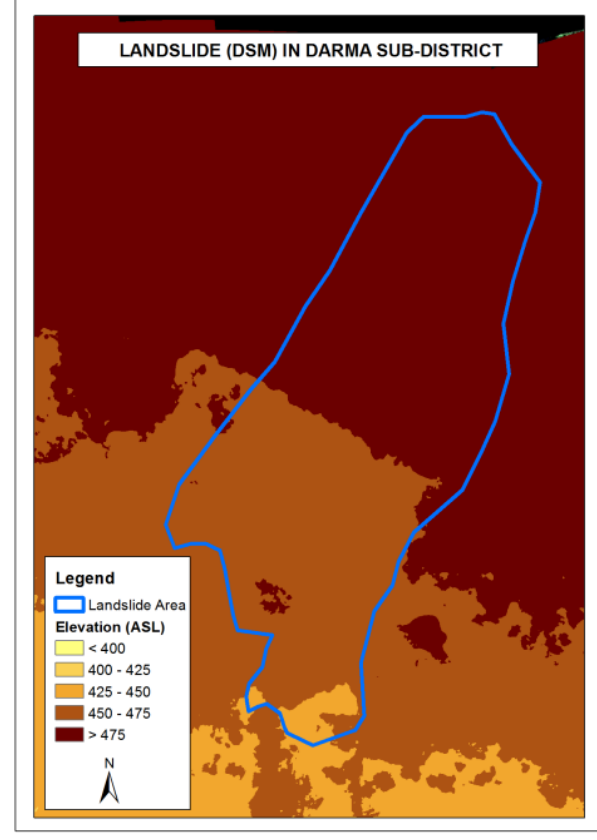

Fig 4. Landslide (DSM) in Darma Sub-District

The second location of the aerial photo was taken in Selajambe District (Fig. 5). In this area, landslides occurred along the main road leading to Selajambe Village. There are 3 landslide points that are in close proximity. These locations were used for soil cut and fill activities for road and housing construction, where it might reduce the retaining force for the slope enable landslide to occur. Topographically, these landslides occur on slopes of $25-45 \%$ and located in the area of plantation. The landslide events made people could not access residential locations in Selajambe District.

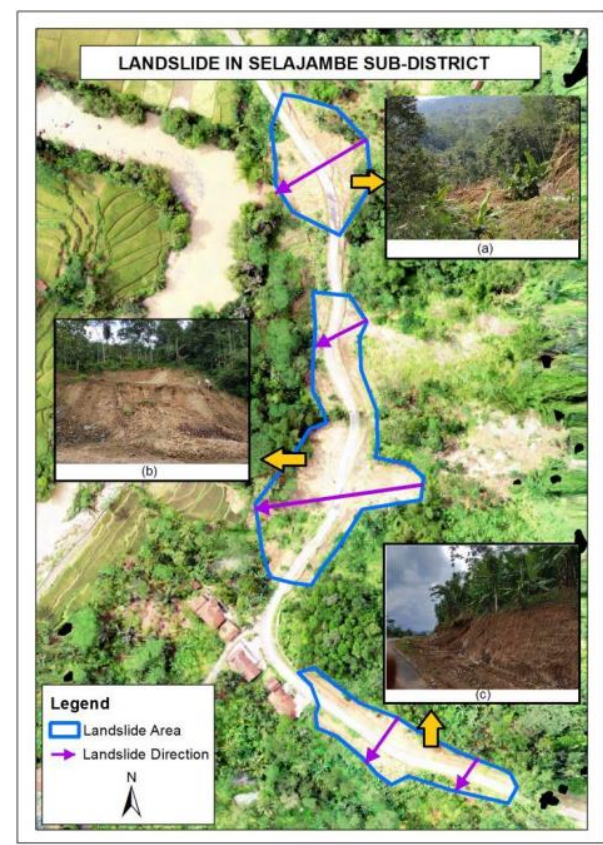

Fig 5. Landslide in Selajambe Sub-District

There are 3 landslide points shown in Figure 5. Point (a) has an area of 2,105.34 $\mathrm{m}^{2}$, point (b) has an area of $4,557.11 \mathrm{~m}^{2}$ while point (c) has an area of 2,036.24 $\mathrm{m}^{2}$. 
The direction of the avalanche at point (a) leads to Southwest, point (b) leads to the West and point (c) towards Southwest.

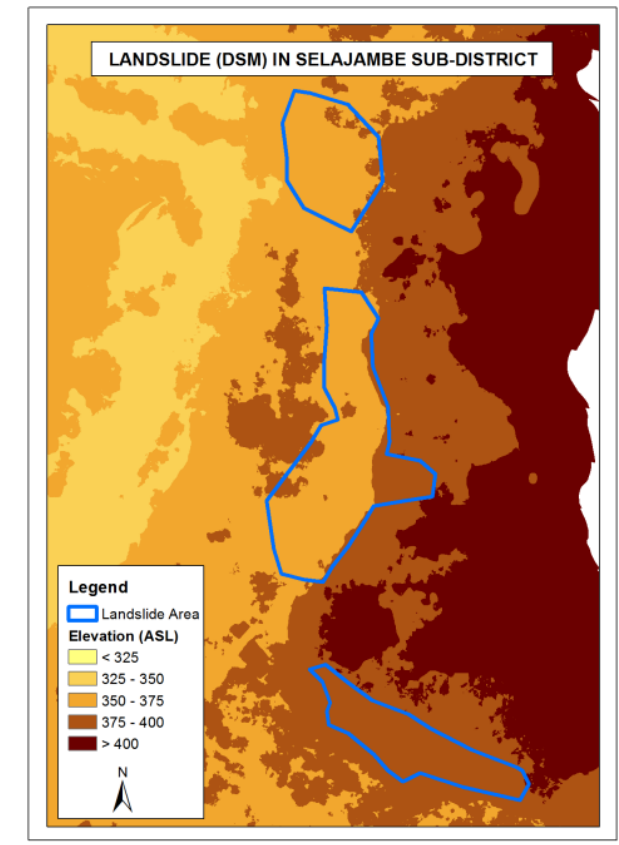

Fig 6. Landslide (DSM) in Selajambe Sub-District

From the results of DSM processing, it can be estimated the height of the avalanche (Fig. 6). The landslide starts from the peak of the slope with an altitude of \pm 380 meter ASL to the sediment area with a height of \pm 350 meter ASL in all three landslide points. The length of this avalanche is between 40-50 meters at landslide points (a), 20 - 80 meters in landslides (b) and 20-25 meters at landslide points (c). From these results, DEM and Orthophoto images can be used technically for landslide mitigation in Kuningan Regency.

Based on the results of 2 aerial photography shows that UAV technology can be used in landslide mapping because it has several advantages. In research conducted by Wulan et al. explained that UAVs have advantages in time and cost efficiency, especially in mapping rapid landslide areas [7]. Lindner et al. also explained in their research that UAVs are suitable for landslide monitoring as well as for monitoring small-scale soil mass movements $\left(<1 \mathrm{~km}^{2}\right)$ [13]. The disadvantage of the UAV is that the battery life runs out quickly.

\section{Conclusion}

In this study, UAV technology provides Orthophoto and Digital Surface Model (DSM) images with a spatial resolution of $10 \mathrm{~cm}$. Based on the results, Orthophoto and DSM images from UAV are very helpful in identifying areas affected by landslides, especially in areas that are difficult to reach. Profitably, the results can be used to predict the safe zone and distance in building residential areas and roads.

\section{References}

1. A.D. Effendi, Identifikasi Kejadian Longsor dan Penentuan Faktor-faktor Utama Penyebabnya di Kecamatan Babakan Madang Kabupaten Bogor, Departmen Manajemen Hutan, Fakultas Kehutanan Institut Pertanian Bogor (2008)

2. L. Triwahyuni, Sobirin, R. Saraswati, Analisis Spasial Wilayah Potensi Longsor dengan Metode SINMAP dan SMORPH di Kabupaten Kulon Progo Daerah Istimewa Yogyakarta, Seminar Politeknik Negeri Bandung, 69-76 (2017)

3. L.M. Highland, P. Bobrowsky, The Landslide Handbook-A Guide to Understanding Landslides: Reston, Virginia, U.S, Geological Survey Circular (2008)

4. A.S. Muntohar, Tanah Longsor: Analisis, Prediksi dan Mitigasi, LP3M UMY (2010)

5. Sutikno, Mengenal Tanah Longsor, Direktorat Geologi Tata Lingkungan Departemen Pertambangan dan Energi. (2001)

6. B. Andriono, Wilayah Rentan Tanah Longsor di Sepanjang Alur Ci Tarik DA Ci Tarik Kabupaten Sukabumi. Skripsi, Depok: University of Indonesia. (2012)

7. T.R. Wulan, W. Ambarwulan, A.S. Putra, F. Ibrahim, M.D. Putra, D. Maryanto, P. Ferrari, E. Maulana, Pemetaan Cepat Kawasan Terdampak Bencana Longsor dan Banjir di Kabupaten Bangli, Provinsi Bali, Majalah Geografi Indonesia 31, 4450 (2017)

8. BPS Kabupaten Kuningan, Kabupaten Kuningan dalam Angka 2017 (2018)

9. B.R. Barus, Y. Prasetyo, H. Ah, Analisis Akurasi Pemodelan 3D Menggunakan Metode Close Range Photogrammetry (CRP), Unmanned Aerial Vehicle (UAV) dan Terrestrial Laser Scanner (TLS), Jurnal Geodesi Undip 6, 169-179 (2017)

10. Y. Kristiawan, Sumaryono, M.N. Firmansyah, A. Solihin, M.F. Dwiyono, Aplikasi UAV Drone Untuk Penanggulangan Cepat Potensi Aliran Bahan Rombakan (Banjir Bandang) Studi Kasus di Desa Lebakwangi, Kecamatan Arjasari, Kabupaten Bandung, Seminar Nasional Kebumian ke-10, 9 (2017)

11. DJI, Phantom 4 Specs, https://www.dji.com/id, Accessed 20 Jun 2019

12. Agisoft, Official Afisoft Homepage, https://www.agisoft.com, Accessed 15 Jun 2019

13. G. Lindner, K. Schraml, R. Mansberger, J. Hübl, $U A V$ monitoring and documentation of a large landslide, Applied Geomatics (2015) 